INSIGHTS INTO REGIONAL DEVELOPMENT

ISSN 2669-0195 (online) http://jssidoi.org/IRD/

2021 Volume 3 Number 1 (March)

http://doi.org/10.9770/IRD.2021.3.1(2)

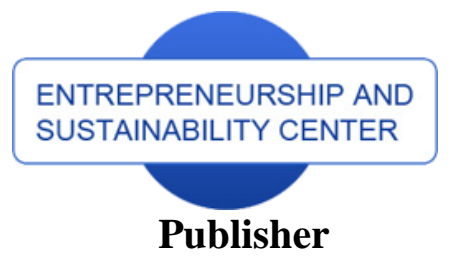

enterprise

europe

network

Business Support on Your Doorstep

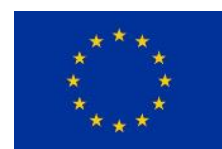

http://jssidoi.org/esc/home

\title{
RESEARCH OF CITIZENS' BEHAVIOR IN A POLITICAL CAMPAIGN IN SEARCHING FOR AND MONITORING POLITICAL ADVERTISING IN THE SLOVAK REPUBLIC*
}

\author{
Marcel Lincényi ${ }^{1}$, Jaroslav Čársky ${ }^{2}$ \\ 1,2 Alexander Dubček university of Trenčin, Študentská 1639/2, 91101 Trenčín, Slovakia \\ E-mails: ${ }^{1}$ marcel.lincenyi@tnuni.sk $;{ }^{2}$ jaroslav.carsky@tnuni.sk
}

Received 16 July 2020; accepted 18 December 2020; published 30 March 2021

\begin{abstract}
The research study thematically focuses on the behaviour of citizens of the Slovak Republic in the campaign for active search and monitoring of political advertising. The authors tried to find out the degree of effectiveness of the use of marketing tools and forms of political advertising. Among other things, the research showed that most of the interviewed Slovaks are actively interested in political advertising in the election campaign. Research has shown that the most effective political advertising is in the audiovisual and online media and, conversely, the least effective in the print media, pre-election leaflets and billboards.
\end{abstract}

Keywords: Slovak Republic; politics; public opinion; marketing; marketing tools; political advertising

Reference to this article should be made as follows: Lincényi, M., Čársky, J. 2021. Research of citizens' behavior in a political campaign in searching for and monitoring political advertising in The Slovak Republic. Insights into Regional Development, 3(1), 29-40. https://doi.org/10.9770/IRD.2021.3.1(2)

JEL Classifications: F50, F68, Z11

Additional disciplines: General, Policy, Economics of the Arts and Literature

\footnotetext{
* This research was carried out in the framework of the project KEGA 003TnUAD-4/2018: Innovation of methodological letters for teachers of civic education from the point of view of prevention of manifestations of extremism and education for democratic citizenship
}
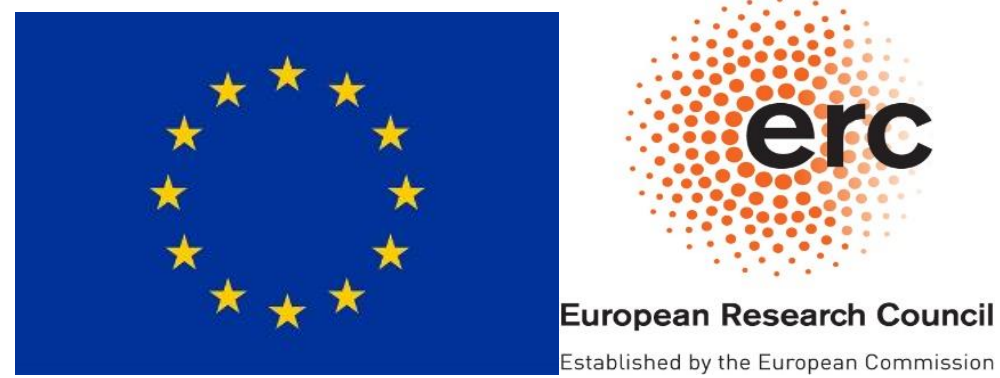
INSIGHTS INTO REGIONAL DEVELOPMENT

ISSN 2669-0195 (online) http://jssidoi.org/jesi/

2021 Volume 3 Number 1 (March)

http://doi.org/10.9770/IRD.2021.3.1(2)

\section{Introduction}

Political marketing began in the second half of the 20th century and has since become an integral part of political science, but especially of election campaigns. "In Slovakia, marketing has been applied in politics since 1989." (Lincényi, 2011: 46) At the beginning of the 1990s, it was used as an essential tool in the final results of the June 1992 elections. The winners Václav Klaus and Vladimír Mečiar agreed on a peaceful and constitutional division of the Czech and Slovak Federal Republics into two independent states. (Mindár, 2019) In recent years, marketing has shifted to the online environment, where, according to Lincényi, the application of marketing principles on the Internet is applied. It is mainly about creating websites, advertising on the Internet, but also marketing research on the Internet, trading on the Internet and more." (Lincényi, 2011: 29) The very importance of online advertising as a part of complex integrated marketing communications has continuously been growing recently. Its effectiveness is high and other experts (Kádeková \& Holienčinová, 2018, Bulanda \& Vavrečka, 2019, Bulanda, Koprda \& Kurimská, 2020) mention that in the near future, this form of advertising will dominate (Světlík, 2017; Stoian, Polozova, Didenko, Storozhenko \& Moskvichova, 2018; Darsono, Susana, Prihantono \& Kasim, 2019; Yunus, Susilo, Riyadi, Indrasari \& Putranto, 2019; Pavlovaite \& Griesiene 2019). A new trend that is beginning to be used in politics is online marketing (Winter, Litvinova, Babaskin, Babaskina, \& Savinova, 2019; Lysytsia, Martynenko, Prytychenko, Gron \& Us, 2019; Ajina, 2019; Danko, Kiselev, Chaykovskaya, Smelov, Sekerin, \& Gorokhova, 2020).

The effectiveness of online political marketing we can monitor through various social networks such as Facebook or Instagram. The effectiveness of political marketing on social networks can be monitored through likes and also by the number of shares. Politicians are thus getting closer and closer to the citizens of the gifted base, because if a politician publishes something on the Internet, an attitude or an idea, it automatically allows the citizens to react. Politicians thus receive feedback from citizens, which is also crucial for them when creating politics. Communication between politicians and the public is vital for the healthy functioning of society. Online marketing, respectively, internet marketing means, application of marketing principles on the internet. Online marketing, like other marketing tools, has evolved and tried to be as addressable as possible to the consumer. A political party or political representatives need to determine the target group. According to this target group, political communication itself will take place, followed by political marketing. The size of the target group is also an important factor. A political party or political representatives must take into account their financial resources, which they can spend on a political campaign. The goal of political marketing and political communication is to reach the target group. Therefore, at the very beginning, the question is to determine the target group so that political marketing is targeted. Political communication plays an essential role in shaping public opinion. Public opinion, in turn, influences the election results. From this point of view, it can be concluded that political communication is one of the critical factors for the election results. About ten years ago, domain creation was widespread; today, a social network page is enough. Time is moving forward very fast, and marketers are coming up with the most convenient way to sell information to ordinary people. "The most popular social network today is Facebook, which has about 2 billion users. This significant interest in the social network Facebook was also noticed by political marketers and politicians themselves." (Čársky, 2019: 53) People spend a lot of time on social networks, so, understandably, political advertising or other political content cannot be avoided. There are many political leaders on social networks who publish their thoughts, attitudes and opinions on current events in society every day. They draw attention to possible risks and, in particular, communicate with the general public through comments. The number of registered users is increasing on social networks every day. On this basis, the potential base of supporters of the given political parties or political representatives may also grow. Online marketing is not a novelty, but it can be effectively published in Slovakia. It is clear that in today's digital age, the public has better resources and a chance to find any political mistakes. It is well known that political wrongdoing harms the politicians involved. (Brosius, 2020) "However, some scientists consider populist attitudes only as a further measure of existing and established concepts, such as 


\section{INSIGHTS INTO REGIONAL DEVELOPMENT}

ISSN 2669-0195 (online) http://jssidoi.org/jesi/

2021 Volume 3 Number 1 (March)

http://doi.org/10.9770/IRD.2021.3.1(2)

political trust and external political effectiveness." (Geurkink, Zaslove, 2020, p. 247) Based on established marketing communication, politicians try to gain as many supporters as possible. On the other hand, it can be a problem not to slip into populism. (Čársky, Lincényi, 2020) Populism is currently a potent political marketing tactic too. An example is that in the last decade, nationalist and populist political parties, such as Alternative for Deutschland, the Dutch Freedom Party, the French National Front, the Czech Freedom and Direct Democracy, and the Slovak Kotleba - People's Party of our Slovakia, have entered their national parliaments with this tactic. (Laczko, Lincényi, 2020) However, populism does not provide real solutions to the political demands of citizens, so it is usually just an incorrect introduction of voters to gain power. Trends in the use of a populist strategy to shape current political processes are often associated with unrealistic political agendas and promises (eg, double-wage increases). "(Vlčej, 2018: 79) Populism can be seen as one aspect of the marketing strategy. Populism is generally and currently taken negatively. If a political leader has the label of "populist" for many, he becomes untrustworthy. There are several definitions of populism, and they agree more on something less. In English, the term populism can be characterised as "a loaded word", i.e. a term that encompasses everything, but its exact meaning or meaning is not clear. Populists do not hesitate to use tools such as misinformation, hoaxes or deceptive propaganda in their political marketing. "It is crucial to know how to protect against false messages on the Internet. We should adhere to the principle that any information we choose to trust should be verifiable from multiple independent sources." (Laczko, 2019: 146)

\section{Methodology and methods}

The main goal of the presented research was to analyse the behaviour of citizens in the political campaign in searching for and monitoring political advertising in the Slovak Republic.

The secondary goal of the research was to determine the degree of effectiveness of the use of tools and forms of political advertising in marketing from the perspective of the citizens of the Slovak Republic.

As part of research planning and design, we preferred the concept of creating research questions to identifying research problems. We have identified the following three issues:

RQ1: To what extent do Slovak voters actively search for and watch political advertising in the campaign?

Explanation RQ1: We think that despite the low confidence of citizens in political institutions in the Slovak Republic, citizens are still actively interested in political events. The answer to this research question will be determined based on the responses from items 1 and 2 of our questionnaire.

RQ2: From which tools of political marketing do the citizens of the Slovak Republic obtain the most frequent political information?

Explanation RQ2: We think that the digital revolution in the world is also having an impact on the political space. Therefore, there is a presumption that citizens will not obtain information from tools that were in place twenty years ago. Therefore, we consider it essential to gain knowledge about the preferred marketing tools in politics. The answer to this research question will be found from the items of questionnaire no. 3-4.

RQ3: Which tools of political marketing are considered by the citizens of the Slovak Republic to be the most effective and which, on the contrary, are the least effective? 
Explanation RQ3: We perceive it important to obtain information on influencing citizens in political marketing. The researched data can thus meet the recommended nature of applicability for practice. The answer to the above research question will provide us with answers from questions no. 7, 8, 9, 10 of our questionnaire.

At the end of 2019, we conducted the survey on a research sample of 968 respondents, while its completion was ensured by 20 trained, experienced interviewers in person in the field.

The research sample consisted of 500 men and 468 women. If we look at the research group by age, 401 respondents were 18 to 29 years old, 123 were aged 30 to 39 years, 184 were aged 40 to 49 years, 182 were aged 50 to 59 years, and 78 respondents were aged 60 years and older. Respondents from the research group came from the Bratislava Region (132), the Trnava Region (186), the Nitra Region (120), the Trenčín Region (102), the Žilina Region (145), the Banská Bystrica Region (89), the Košice Region (100), and the Prešov Region (94).

\section{Results of the analysis}

The research showed that two-thirds of the interviewed Slovaks are actively looking for political advertising, of which 410 respondents are definitely looking for, and 208 respondents are looking for political advertising. Onethird of the respondents have the opposite opinion, while the remaining respondents could not answer this question. (More: Graph No.1)

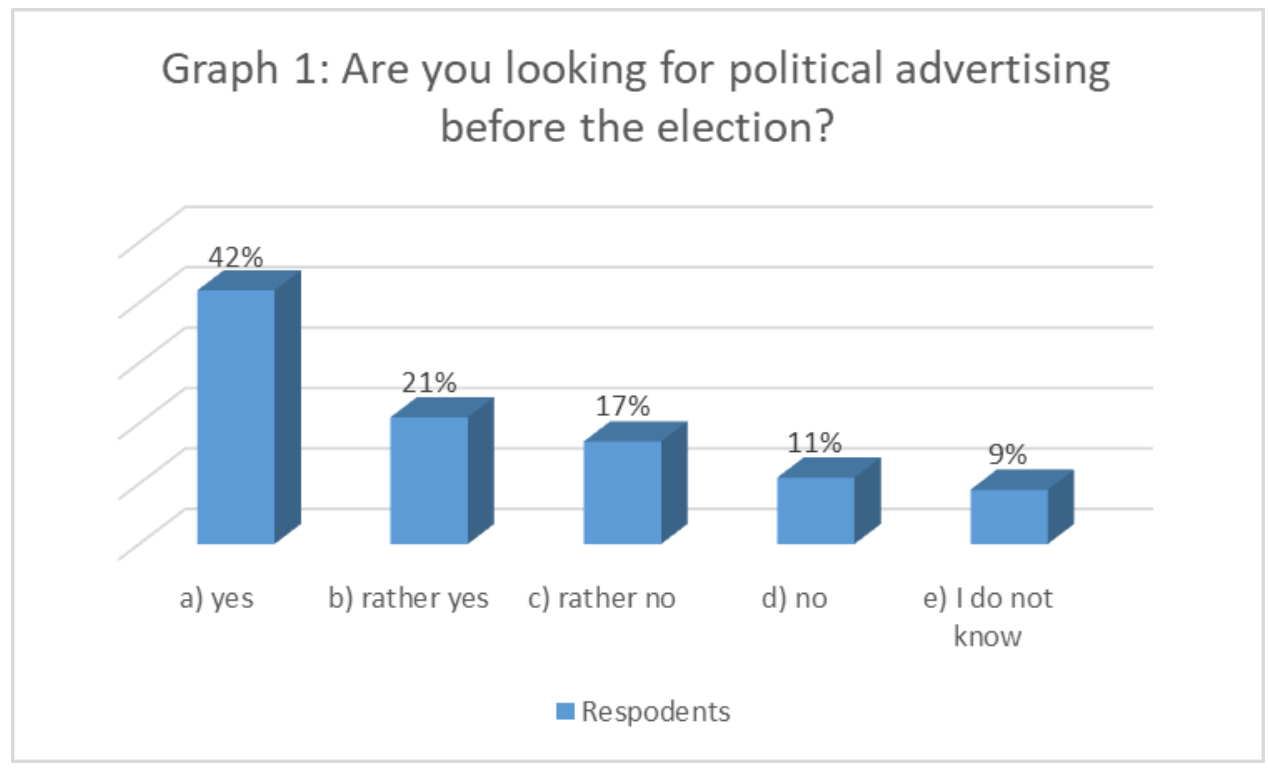

The presented research showed that more than two-thirds of Slovak respondents watch political advertising, of which 499 respondents certainly watch political advertising, and 296 respondents watch political advertising. Less than one-third of the respondents were of the opposite opinion, and the remaining respondents could not answer this question. (More: Graph No.2) 


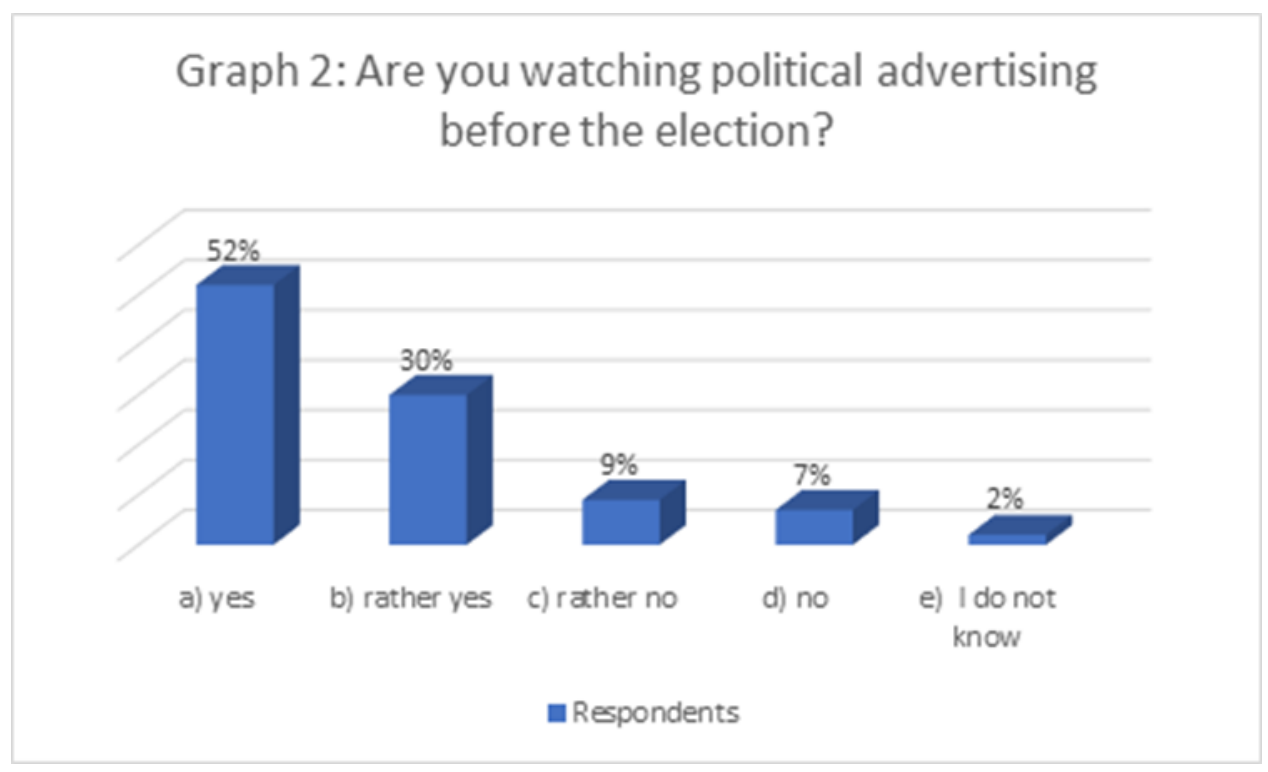

Almost three-quarters of the Slovaks surveyed said that they get the most frequent information about politics and political events through audiovisual media. In the second place, responding Slovaks mentioned social networks, where 598 respondents chose this option. In third place was the Internet media, selected by 460 interviewed Slovaks. (More: Graph No. 3)

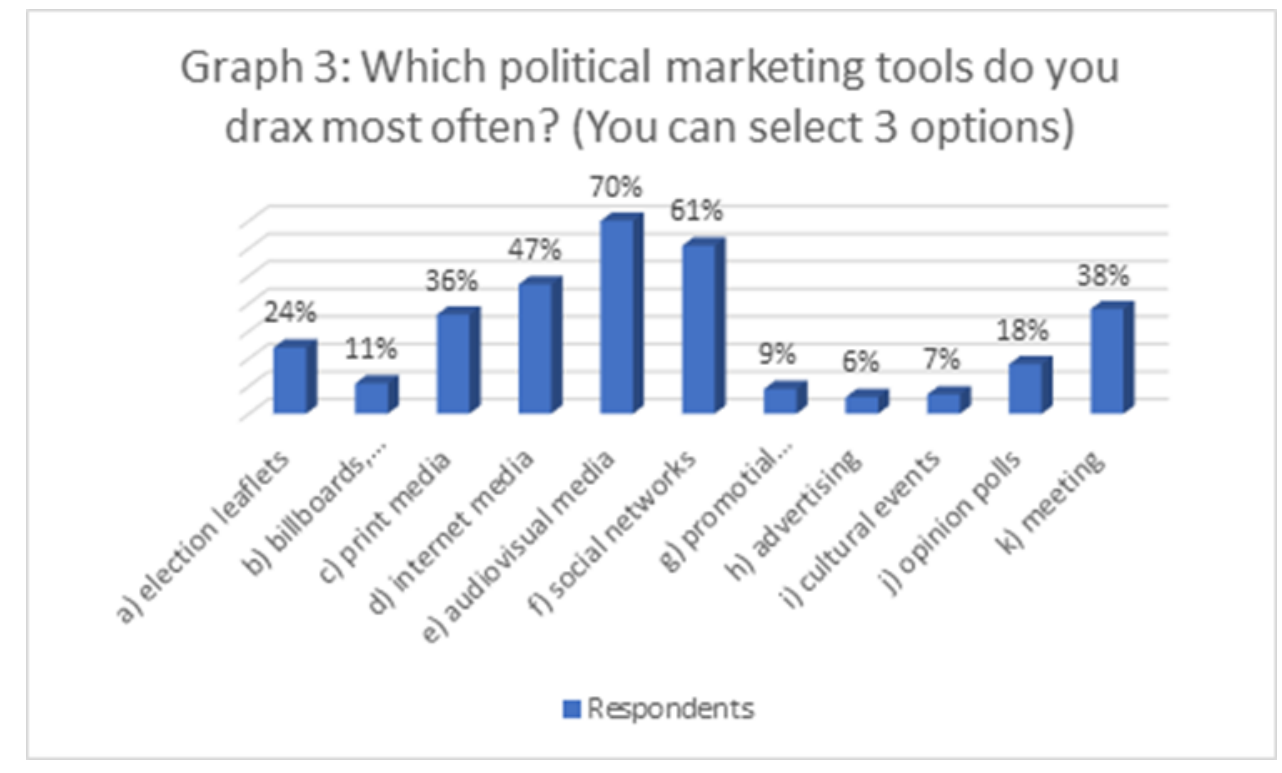

More than one third, it's 401 Slovak respondents stated that they get the least information about politics and political events from election leaflets. One-third of Slovak respondents stated that they do not obtain information about political events through the print media, where 365 respondents indicated this possibility and from promotional materials chosen by 302 respondents. (More: Graph No. 4) 


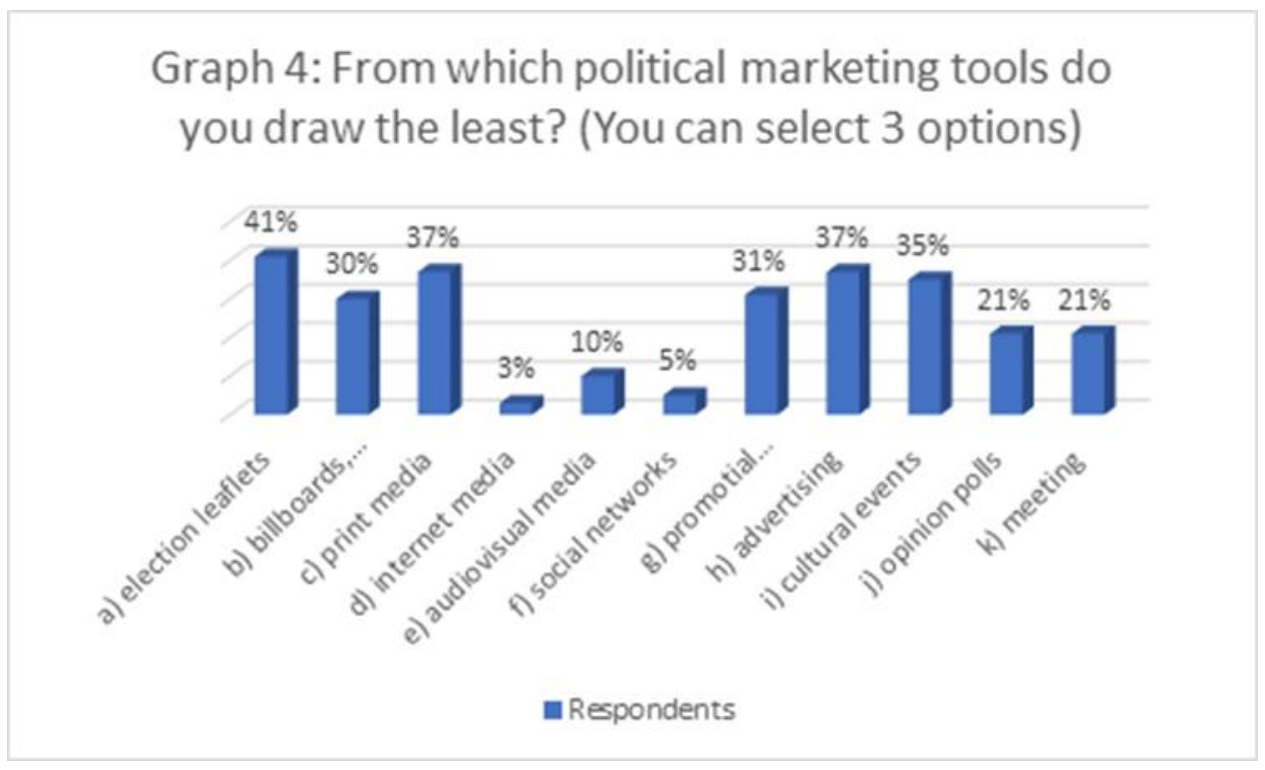

In the following question, we found out which of the tools of political marketing are perceived by the citizens of the Slovak Republic as the most effective. More than a third of respondents mentioned social networks and internet media, of which 403 respondents think that social networks are the most effective tool for political marketing, followed by internet media, where 388 respondents mentioned this option. In third place was the audiovisual media, where 286 respondents indicated this possibility. (More: Graph No. 5)

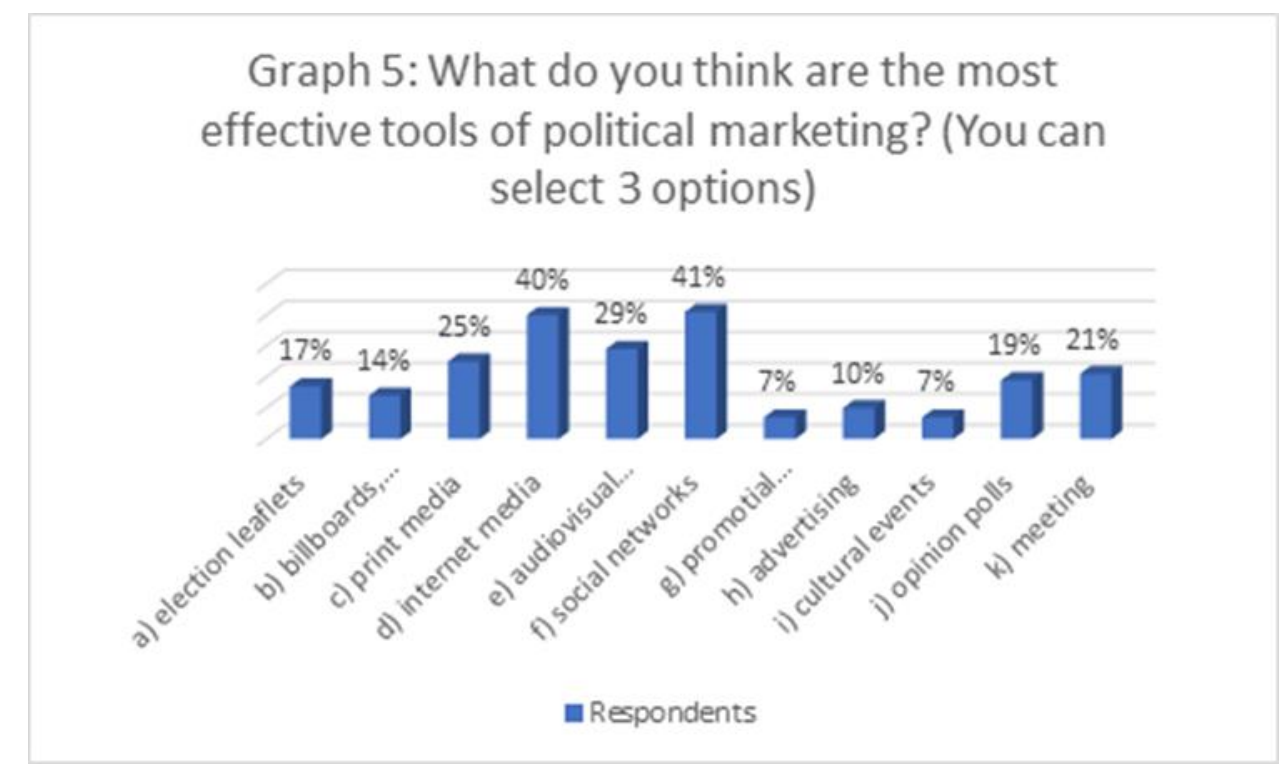

Our research shows that more than one-third of Slovaks surveyed think that the least useful tool for political marketing is paid to advertise. In the second place, citizens consider promotional materials to be the least 
effective, where 343 respondents indicated this possibility. In third place, 301 respondents cited election leaflets and billboards, billboards and city lights as least effective. (More: Graph No. 6)

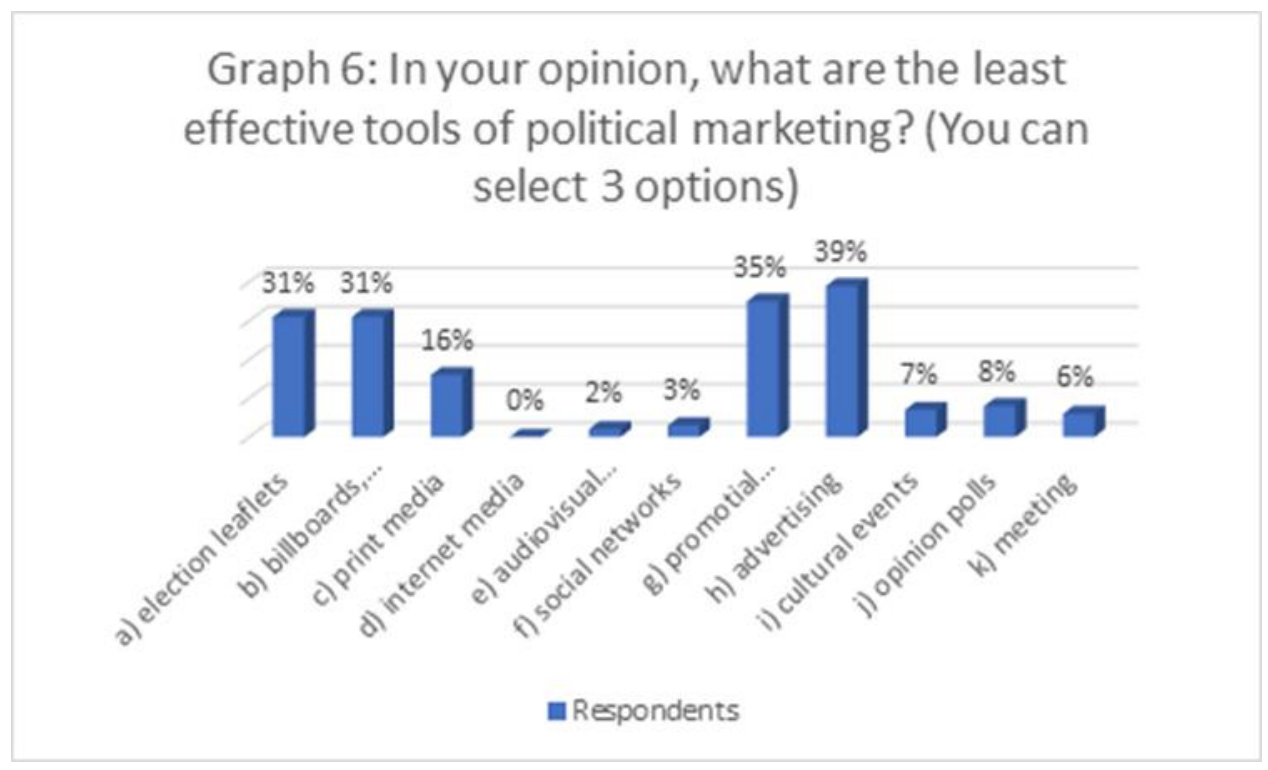

In the seventh question, we asked the respondents how they are influenced by political advertising in the online media. Two-thirds of the surveyed Slovaks stated that they are influenced by political advertising in this type of media. Of these, 361 respondents stated that internet media certainly influence them, 342 respondents indicated that they slightly influence them. Almost one-third of Slovak respondents have the opposite opinion. The remaining respondents could not answer this question. (More: Graph No. 7)

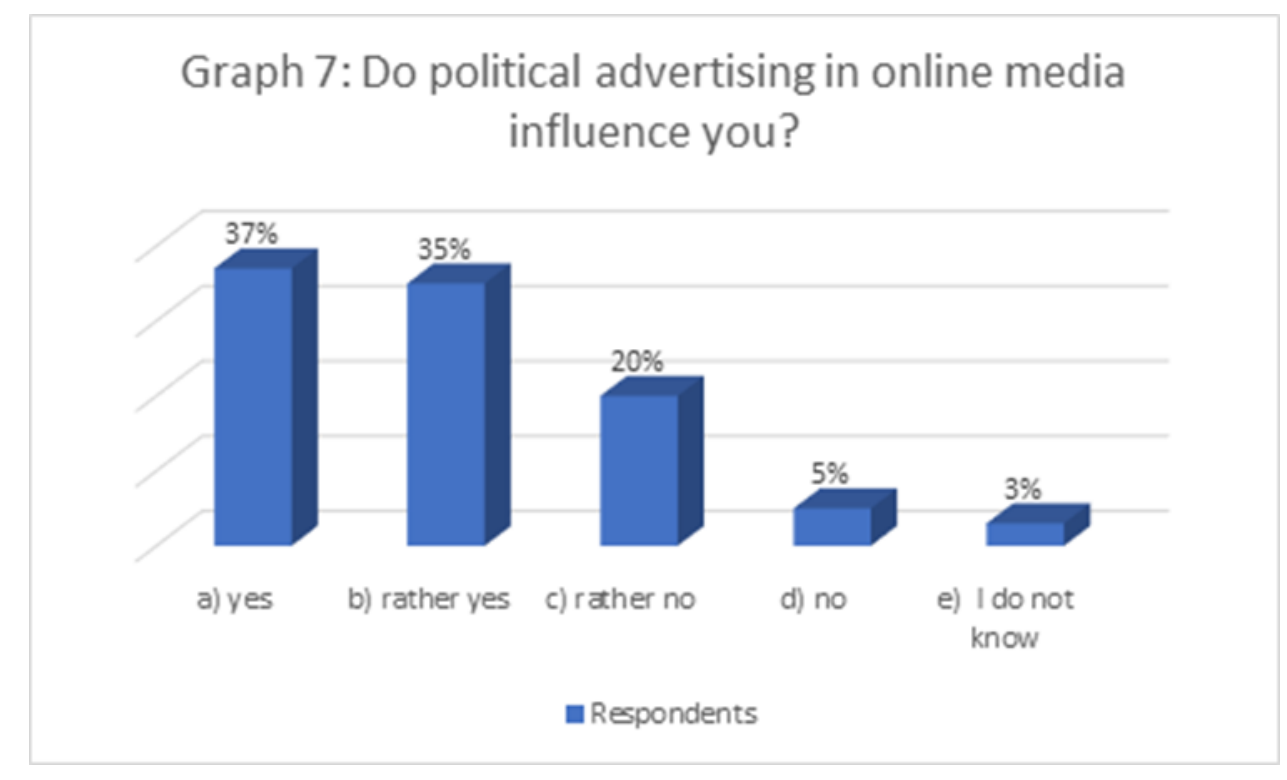


In the eighth question, we found out from the respondents how much they are influenced by political advertising in the print media. Two-thirds of Slovaks surveyed said they did not feel influenced by print advertising. 399 respondents stated that their advertising in the print media did not affect them at all. Rather, political advertising in the press does not affect 204 respondents. One third of respondents are of the opposite opinion. The other respondents could not answer this question. (More: Graph No. 8)

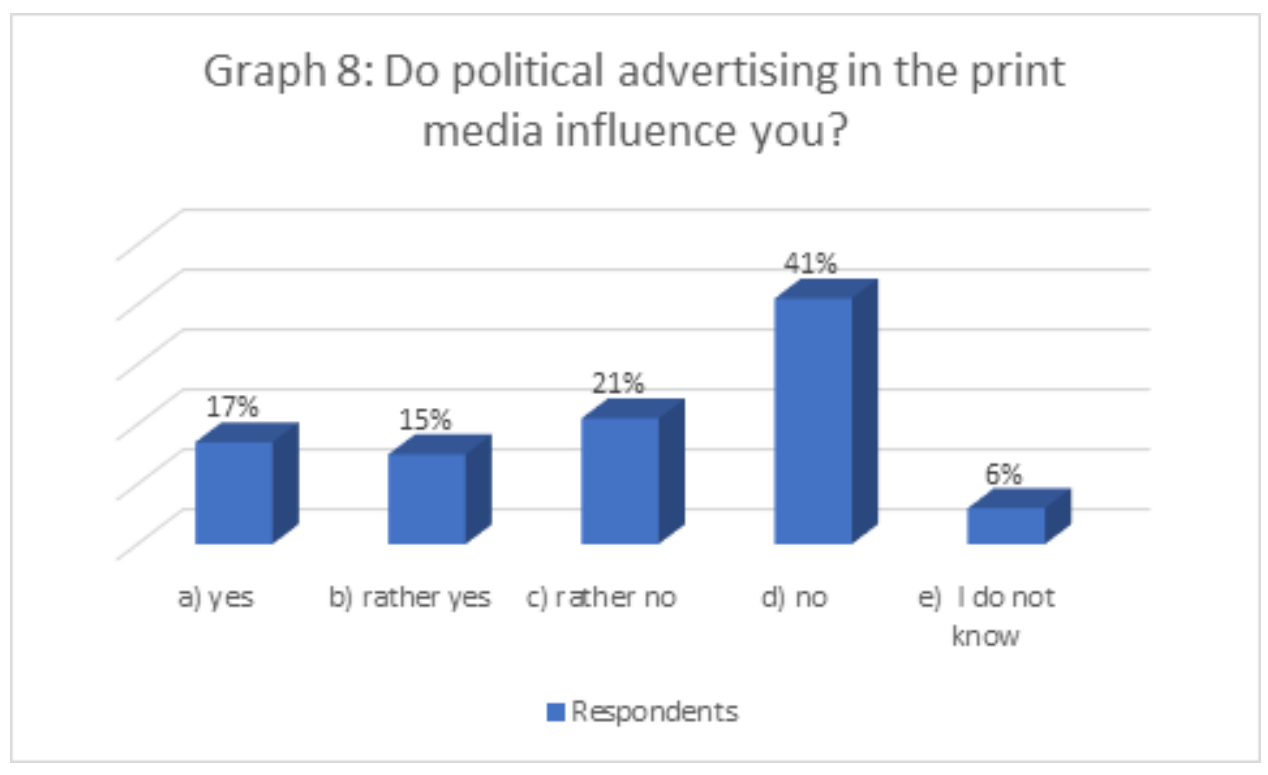

In the ninth question, we asked the respondents' opinion on the influence of political advertising on television and radio. Half of the interviewed Slovaks stated that they are influenced by television and radio. Of these, 298 respondents chose the possibility that their political advertising on television and radio influenced them, 194 respondents stated that they rather influence them. More than one-third of Slovaks surveyed had the opposite opinion. The remaining respondents could not answer this question. (More: Graph No. 9)

\section{Graph 9: Do political advertising on television and radio influence you?}

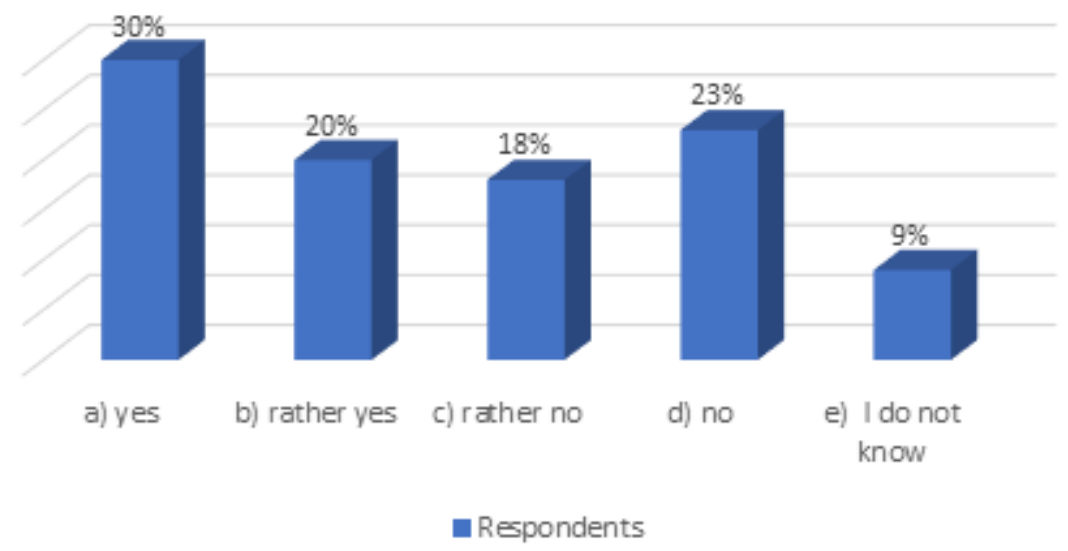


In the last question, we asked the citizens of the Slovak Republic, whether they are also influenced by other political advertising than they have been mentioned so far in the questionnaire. Almost all interviewed Slovaks (887 respondents) stated that they are not influenced by political advertising other than those mentioned in the questionnaire. Eighty-one respondents indicated political advertising in the form of e-mails. (More: Graph No. 10)

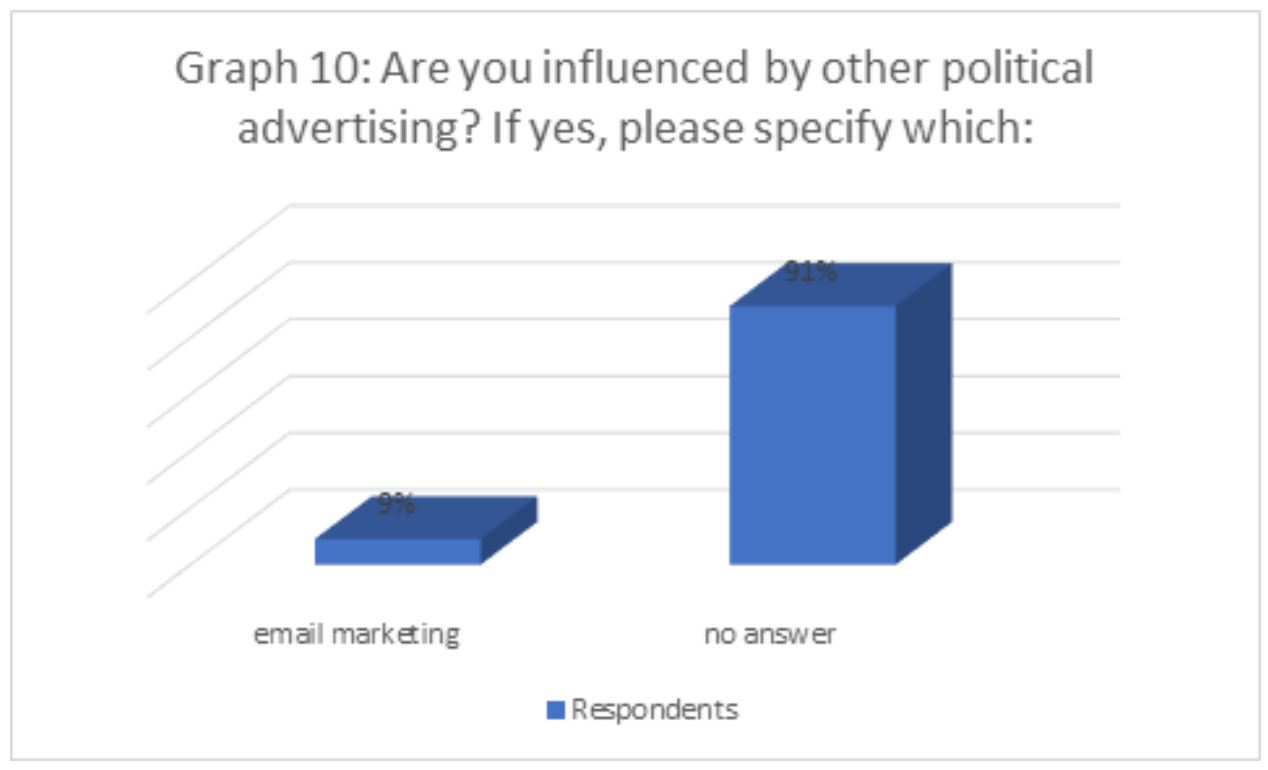

\section{Discussion}

In the first research question, we believed that despite the relatively low confidence of the citizens of the Slovak Republic in political institutions, the interest in political events is still relatively high. This assumption was confirmed in the research, as the majority of citizens of the Slovak Republic still perceive the need to be interested in political events. As many as two-thirds of respondents are actively seeking information on politics. Of interest was the fact that more than three-quarters of respondents watch political advertising.

In the second specific research question, we thought that the citizens of the Slovak Republic would not obtain information from the tools that were current twenty years ago. We wanted to point out that humanity is experiencing a digital revolution that is also having an impact on the political space. People buy print media less, but get information from online sources. We were not able to unequivocally confirm this statement based on the respondents' preferences. Research shows that the most common citizens use audiovisual media to find out about politics, while the least frequent ones are through ballot papers. Among the most effective tools of political marketing, respondents mentioned social networks, while other promotional materials are the least effective.

In the last specific research question, we focused on the impact of political advertising on individual media. It is clear from the results that citizens have seen the most significant impact of political advertising on online media. Television and radio came in second, and citizens mentioned print media in the last place. The last research question, therefore, demonstrably shows that the digital age also has an impact on the political space. Citizens are thus focusing on information through the internet, and information in print is coming back. 


\section{INSIGHTS INTO REGIONAL DEVELOPMENT}

ISSN 2669-0195 (online) http://jssidoi.org/jesi/

2021 Volume 3 Number 1 (March)

http://doi.org/10.9770/IRD.2021.3.1(2)

\section{Conclusions}

Political marketing has become an integral part of political life in the 21 st century. Increasingly, political leaders are focusing on quality communication with the public than on the political agenda. Thanks to modern technologies, which can also include social networks, communication between political representatives and the public are becoming easier. The public can directly ask which policy can solve problems. Today, no politician can implement marketing strategies just during an election campaign. With the help of marketing tools, political leaders are always trying to convince citizens of their ideas. In the Slovak Republic, political marketing began to develop after 1989, i.e. after the liberation of the then regime. Following the fall of the totalitarian regime, political parties were allowed to run in elections, creating political competition. As the country developed, so did marketing in politics itself. Trends have changed, they have improved the tools of political marketing, and nowadays, there are many ways to do marketing in politics. Political leaders currently appear most often on social networks. Social networks have become an integral part of every person in today's modern society. This space was used by political leaders to present their ideas and the political campaign itself.

Based on the sociological research of the perception of political marketing by the citizens of the Slovak Republic, several starting points and conclusions emerge:

The results of the research provided information on the current state of operation of various political marketing tools. Within the current trends, the citizens of the Slovak Republic are most influenced, or rather they are most affected by the mass media that are located in the online space. Citizens thus obtain political information primarily from their mobile devices. Among other things, the research also confirmed the information that the interviewed citizens are aware of political advertising and its influence on their voting behaviour.

By carrying out this research study, the authors do not claim a comprehensive view of the analysis of the impact of political marketing tools on the citizens of the Slovak Republic concerning the research group. The research topic offers several other processing options. One of them is a survey of voter behavior during the election campaign, in which the influence of individual political parties would be examined on the basis of the use of political marketing tools. Research on political advertising in selected media could be beneficial for science and practice. It would also be interesting to compare the results from Slovakia with other countries of the Member States of the European Union.

\section{References}

Ajina, A. S. 2019. The perceived value of social media marketing: an empirical study of online word-of-mouth in Saudi Arabian context. Entrepreneurship and Sustainability Issues, 6(3), 1312-1327. https://doi.org/10.9770/jssi.2019.6.3(32)

Brosius, A., Elsas, J.E, Vreese, H.C., \& Marquart, F. (2020). How political malpractice affects trust in EU institutions. West European Politics, 43(4), 944-968 ISSN: 01402382. https://doi.org/10.1080/01402382.2019.1667654

Bulanda, I. \& Vavrečka, V. (2019). Perception of commercial advertising by generation y in intentions of transaction analysis. In Marketing Identity - Offline Is the New Online. Conference Proceedings from the International Scientific Conference. Trnava: Faculty of Mass Media Communication, University of SS. Cyril and Methodius in Trnava, pp. 454-470. ISBN 978-80-572-0038-3

Bulanda, I., Koprda, T., \& Kurimská, Z. (2020). Generation Y and its view on online advertising in Slovakia. VŠPP Entrepreneurship Studies, 9(1), 5-12. ISSN 1802-0453. 
INSIGHTS INTO REGIONAL DEVELOPMENT

ISSN 2669-0195 (online) http://jssidoi.org/jesi/

2021 Volume 3 Number 1 (March)

http://doi.org/10.9770/IRD.2021.3.1(2)

Č́rsky, J. \& Lincényi, M. (2020). Policy Trusts in Public Policy in the Slovak Republic. Insights into regional development, 2(1), 456-468. ISSN: 2669-0195. https://doi.org/10.9770/IRD.2020.2.1(5)

Č́ársky, J. (2019). Vybrané nástroje politického marketingu na volebnú kampaň v EÚ (Selected tools of political marketing for the election campaign in the EU) Aktuálne otázky politiky II. 2019. ISBN: 978-80-8075-8387

Danko, T.P., Kiselev, V.M., Chaykovskaya, L.A., Smelov, P.A., Sekerin, V.D., \& Gorokhova, A.E. 2020. Marketing positioning of countries in the field of innovations: questions and answers. Entrepreneurship and Sustainability Issues, 7(4), $2851-2862$.

http://doi.org/10.9770/jesi.2020.7.4(18)

Darsono, J.T., Susana, E., Prihantono, E. Y., \& Kasim, E.S. (2019). Strategic policies for small and medium businesses in marketing through e-commerce. Entrepreneurship and Sustainability Issues, 7(2), 1230-1245. http://doi.org/10.9770/jesi.2019.7.2(30)

Geurkink, B., Zaslove, A., Sluiter, R. \& Jacobs, K. (2020). Populist Attitudes, Political Trust, and External Political Efficacy: Old Wine in New Bottles? Political Studies, 68(1), 247-267. ISSN: 0032-3217. https://doi.org/10.1177/0032321719842768

Kádeková, Z. \& Holienčinová, M. (2018). Influencer marketing as a modern phenomenoncreating a new frontier of virtual opportunities. Communication Today, 9(2), 90-105.

Laczko, M. \& Lincényi, M. (2020). Influence of Brexit on education towards Europeanism. Insights into regional development, 2(4), ISSN: 2669-0195.

Laczko, M. (2019). Misinformation, hoaxes as a tool for destroying a free democratic society. In: Education and training for democratic citizenship in the Slovak Republic. 2019. ISBN 978-80-8075-861-5

Lincényi, M.- Kol. 2011. Marketing (Vybrané kapitoly) Trenčín: KP TNUAD. 2011. ISBN: 978-80-8075-514-0

Lysytsia, N., Martynenko, M., Prytychenko, T., Gron O., \& Us M. 2019. Prospects for innovations in marketing of economic educational services in Ukraine. Entrepreneurship and Sustainability Issues, 6(4), 1771- 1783. http://doi.org/10.9770/jesi.2019.6.4(16)

Mindár, M. (2019). The Principle of Prohibition of Majorization in Czechoslovakia. In: Sborník z VIII. mezinárodní vědecké konference studentů doktorských studijních programů v oblasti společenských věd Olomouc, 30. dubna 2019. (Ed.)Martina Hubálková Praha: Nakladatelství Epocha. p. 135-146.

Pavlovaite, U., \& Griesiene, I. (2019). Development of an Art Platform in Terms of Relationship Marketing: a Biennial Case. Transformations in Business \& Economics, Vol. 18, No 2 (47), 259-278.

Stoian, O., Polozova, T., Didenko, E., Storozhenko, O., \& Moskvichova, O. (2018). Strategies of interaction with a consumer within the marketing product policy, Entrepreneurship and Sustainability Issues, 6(2), 1018-1027. http://doi.org/10.9770/jesi.2018.6.2(36)

Světlík, J. (2017). Integrating online advertising into integrated marketing communications. In: Marketing Identity - Online rules I. Trnava: Faculty of Mass Media Communication, University of Ss. Cyril and Methodius in Trnava, 2017. ISBN 978-80-8105-917-9, p. 206-215. Vlčej, J. (2018). How Slovaks vote. Political development of the Slovak Republic in the period 1989-2018. Brno: Knihovnicka.cz. 2018. ISBN: 978-80-263-1503-2

Winter, E.A., Litvinova, T. M., Babaskin, D. V., Babaskina, L. I. \& Savinova, O. V. 2019. Marketing analysis of the medical representatives' activity aimed on information support for promoted medications. Entrepreneurship and Sustainability Issues, 7(1), 177187. http://doi.org/10.9770/jesi.2019.7.1(14)

Yunus, E., Susilo, D., Riyadi, S., Indrasari, M., \& Putranto, T.D. (2019). The effectiveness marketing strategy for ride-sharing transportation: intersecting social media, technology, and innovation. Entrepreneurship and Sustainability Issues, 7(2), 1424-1434. http://doi.org/10.9770/jesi.2019.7.2(44) 
INSIGHTS INTO REGIONAL DEVELOPMENT

ISSN 2669-0195 (online) http://jssidoi.org/jesi/

2021 Volume 3 Number 1 (March)

http://doi.org/10.9770/IRD.2021.3.1(2)

\section{Acknowledgements}

This research was carried out in the framework of the project KEGA 003TnUAD-4/2018: Innovation of methodological letters for teachers of civic education from the point of view of prevention of manifestations of extremism and education for democratic citizenship

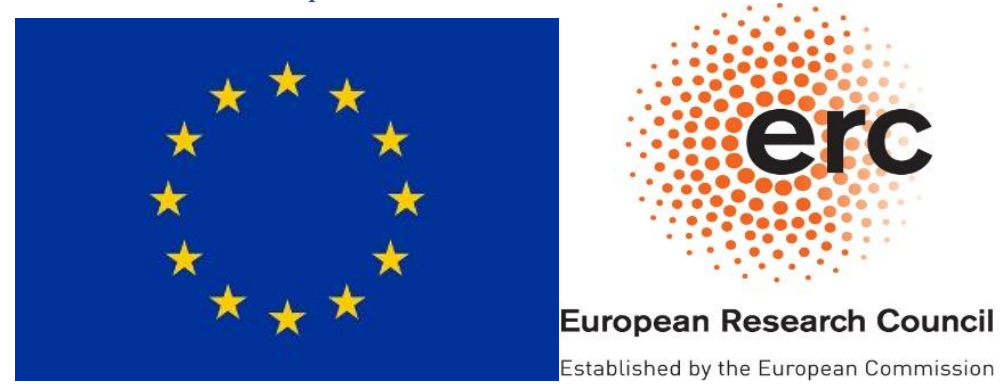

Marcel LINCÉNYI, PhD. in Media studies, obtained at Constantine the Philosopher University in Nitra, currently at Department of Political Science as associate professor, Trenčín University of Alexander Dubček in Trenčín (TnUAD), Slovakia. ORCID ID: https://orcid.org/0000-0002-9076-026X

Jaroslav CARSKY, Mgr. is currently internal PhD. student at the Department of Political Science, Alexander Dubček University of Trenčín in Trenčín

ORCID ID: https://orcid.org/0000-0002-2497-7161

Copyright (C) 2021 by author(s) and VsI Entrepreneurship and Sustainability Center

This work is licensed under the Creative Commons Attribution International License (CC BY).

http://creativecommons.org/licenses/by/4.0/

c) (i) Open Access 